\title{
1 Report of in vitro antileishmanial properties of Iberian macroalgae
}

3 Carolina Bruno de Sousa ${ }^{1}$, João Henrique G. Lago ${ }^{2}$, Jorge Macridachis ${ }^{1}$, Marta

4 Oliveira $^{1,3}$, Luis Brito ${ }^{1}$, Catarina Vizetto-Duarte ${ }^{1}$, Cláudia Florindo ${ }^{4,5}$, Sarah 5 Hendrickx $^{6}$, Louis Maes ${ }^{6}$, Thiago Morais ${ }^{2}$, Miriam Uemi², Luís Neto ${ }^{7}$, Lídia 6 Dionísio $^{7}$, Sofia Cortes ${ }^{3}$, Luísa Barreira ${ }^{1}$, Luísa Custódio ${ }^{1}$, Fernando Alberício ${ }^{8}$, 7 Lenea Campino $^{3}$ and João Varela ${ }^{1 *}$

$8{ }^{1}$ Centre of Marine Sciences, University of Algarve, Campus de Gambelas, 8005-139 Faro, Portugal.

$9{ }^{2}$ Instituto de Ciências Ambientais, Químicas e Farmacêuticas, Universidade Federal de São Paulo, 10 São Paulo 09972-270, Brazil.

$11{ }^{3}$ Global Health and Tropical Medicine Centre, Instituto de Higiene e Medicina Tropical,

12 Universidade Nova de Lisboa, 1349-008 Lisboa, Portugal.

$13{ }^{4}$ Programa de Medicina Regenerativa, Departamento de Ciências Biomédicas e Medicina, UAlg, 14 8005-139 Faro, Portugal.

$15{ }^{5}$ Centro de Investigação Biomédica, University of Algarve, 8005-139 Faro, Portugal.

$16{ }^{6}$ Department of Biomedical Sciences, Faculty of Pharmaceutical, Biomedical and Veterinary

17 Sciences, Antwerp University, Antwerp, Belgium.

$18{ }^{7}$ Faculdade de Ciências e Tecnologia, University of Algarve, Faro, Portugal.

$19{ }^{8}$ Institute for Research in Biomedicine, Barcelona Science Park, Barcelona, Spain.

$21 *$ Corresponding author. Email: jvarela@ualg.pt

\section{Acknowledgments}

23 This work was supported by the Foundation for Science and Technology (FCT) and the Portuguese 24 National Budget under the grants PTDC/MAR/103957/2008 and CCMAR/Multi/04326, GHTM25 UID/Multi/04413/2013 projects; SFRH/BD/78062/2011, SFRH/BD/81425/2011, IF/00049/2012 and 26 IF/00743/2015 grants; and the Brazilian institutions, Coordenação de Aperfeiçoamento de Pessoal de 27 Nível Superior (CAPES), Fundação de Amparo à Pesquisa do Estado de São Paulo (FAPESP) and 28 Conselho Nacional de Desenvolvimento Científico e Tecnológico (CNPq). 


\section{Report of in vitro antileishmanial properties of Iberian macroalgae}

\section{Abstract}

32 Here is reported the anti Leishmania infantum activity of 45 hexane, dichloromethane and 33 ethanol extracts from 16 macroalgae collected on the Iberian Coast. Seven hexane and dichloromethane Cystoseira baccata, C.barbata, C. tamariscifolia, C. usneoides, Dictyota spiralis and Plocamium cartilagineum extracts were active towards promastigotes $\left(\mathrm{IC}_{50} 29.8\right.$ $101.8 \mu \mathrm{g} / \mathrm{mL}$ ) inducing strong morphological alterations in the parasites. Hexane extracts of C. baccata and C. barbata were also active against intracellular amastigotes $\left(\mathrm{IC}_{50} 5.1\right.$ and 6.8 $\mu \mathrm{g} / \mathrm{mL}$, respectively). Fatty acids, triacylglycerols, carotenoids, steroids, and meroterpenoids were detected by nuclear magnetic resonance (NMR), and gas chromatography (GC) in the Cystoseira extracts. These results suggest that Cystoseira macroalgae contain compounds with antileishmanial activity, which could be explored as scaffolds to the development of novel sources of antiparasitic derivatives.

Keywords: Antiparasitic, Leishmania infantum; Leishmaniasis; Macroalgae; Cystoseira; Secondary metabolites.

\section{Introduction}

Leishmaniases are vector-borne diseases caused by Leishmania parasites, and transmitted by phlebotomine sand flies, which affect more than 12 million people in 98 countries (Alvar et al. 2012). Drugs available for controlling leishmaniases have serious side effects and limited effectiveness due to growing parasite resistance. In this context, the development of novel drugs is of paramount importance (Sundar \& Chakravarty 2015). Marine resources are recognized as rich sources of compounds for the biodiscovery of novel drug leads which could also be used for antileishmanial therapy and control (Tempone et al.2011). Several macroalgae species show to be toxic to Leishmania parasites however few publications described the identification of promising molecules for future studies regarding leishmaniases treatment (Yamthe et al., 2017). This study evaluated the in vitro activity of hexane (HEX), dichloromethane (DCM) and methanolic $(\mathrm{MeOH})$ extracts of 16 macroalgae species from the Iberian coast against L. infantum, the species responsible for the canine leishmaniasis and the most severe form of human disease, thevisceral leishmaniasis. Results suggested that Cystoseira contain compounds with antileishmanial activity. 


\section{Results and discussion}

Screening of 16 macroalgae extracts using the MTT colorimetric assay enabled the detection of activity against L. infantum promastigotes in six species (Tables S1 and S2). Most of the identified bioactive extracts that decreased promastigote viability by $50 \%$ at concentrations lower than $94 \mu \mathrm{g} / \mathrm{mL}$ belonged to Cystoseira species, effects similar to those obtained for crude extracts of other algae of the same phylum (Yamthe et al., 2017). Altough axenic promastigotes are often used for the in vitro preliminary drug screening, promising products should be evaluated on the clinical relevant stage in the vertebrate host, the intracellular amastigotes (Tempone et al. 2011). C. tamariscifolia and C. usneoides HEX and DCM extracts were the most active $\left(\mathrm{IC}_{50} 29.8\right.$ - $33.6 \mu \mathrm{g} / \mathrm{mL}$ ) against promastigote forms. However, its high toxicity against THP-1 mammalian cells prevented its evaluation upon the intracellular model (Figure 1). Conversely, C. baccata and C. barbata HEX extracts that decreased by half the promastigote viability at 94.1 and $78.7 \mu \mathrm{g} / \mathrm{mL}$ presented good selectivity when assayed against the intracellular model. Incubation with the aforementioned extracts decreased infection by $50 \%$ at 5.1 and $6.8 \mu \mathrm{g} / \mathrm{mL}$, respectively, with cytotoxicity similar to that of the reference drug miltefosine (Figure 1; Table S2). These results showed that the C. baccata and C. barbata HEX extracts displayed higher leishmanicidal activity than those described for other Cystoseira against axenic $\left(\mathrm{IC}_{50}>23.5 \mu \mathrm{g} / \mathrm{mL}\right.$; Süzgeç-Selçuk et al. $2010)$ and intracellular $\left(\mathrm{IC}_{50}>15.7 \mu \mathrm{g} / \mathrm{mL}\right.$; Spavieri et al. 2010) L. donovani amastigotes.

The effect of Cystoseira extracts on promastigotes was also analysed by optical microscopy, revealing the occurrence of morphological changes (Figure S1) similar to those observed after treatment of Leishmania promastigotes with extracts from marine sponges (Kahla-Nakbi et al., 2010). Extracts induced motility loss, cell shrinkage, abnormal round cell shapes, vacuolated and slightly denser cytoplasm as well as reduction of flagellar length in parasite cells (Figure S1D). Loss of motility and cellular vacuolization could be consequence of starvation processes caused by a deficient mitochondrial activity, autophagic mechanisms or cytoplasmic organelle disruption (Lockshin \& Zakeri 2004; Monte Neto et al., 2011). These results together with the absence of phosphatidylserine externalization, observed in promastigotes treated with the extracts for $48 \mathrm{~h}$ (data not shown), suggest that crucial organelles, such as mitochondria, are compromised and that the observed leishmanicidal effect might not be associated with programmed cell death.

Chemical profiles of the active Cystoseira extracts investigated using different analytical methods (NMR, GC/FID and GC/LREIMS) reveal the occurrence of different classes of 
93 metabolites (Table S3; Figures S2 and S3)in agreement with previous studies focusing on 94 Cystoseira (Bruno de Sousa, et al. 2017a). Unsaturated fatty acids such as arachidonic and

\section{Disclosure statement}

113 No potential conflict of interest was reported by the authors.

\section{References}

115 Alvar J, Vélez ID, Bern C, Herrero M, Desjeux P, Cano J, Janni J, Boer MD. 2012. Leishmaniasis

116 worldwide and global estimates of its incidence. PLoS One. 7:e35671.

117 Bekele B, Adane L, Tariku Y, Hailu A. 2013. Evaluation of antileishmanial activities of triglycerides 118 isolated from roots of Moringa stenopetala. Med. Chem. Res. 22:4592-4599.

119 Bruno de Sousa C, Gangadhar KN, Macridachis J, Pavão M, Morais TR, Campino L, Varela J, Lago 120 JHG. 2017b. Cystoseira Algae (Fucaceae): Update on their Chemical Entities and Biological 121 Activities. Tetrahedron: Asymmetry. https://doi.org/10.1016/j.tetasy.2017.10.014 
122 Bruno de Sousa C, Gangadhar KN, Morais TR, Conserva GA, Vizetto-Duarte C, Pereira H, Laurenti 123 MD, Campino L, Levy D, Uemi M, Barreira L, Custódio L, Passero LF, Lago JH, Varela J. 2017 a.

124 Antileishmanial activity of meroditerpenoids from the macroalgae C. baccata. Exp. Parasitol. 174:1-9.

125 Gray CA, de Lira SP, Silva M, Pimenta EF, Thiemann OH, Oliva G, Hajdu E, Andersen RJ, Berlinck 126 RGS. 2006. Sulfated meroterpenoids from the Brazilian sponge Callyspongia sp. are inhibitors of the 127 antileishmaniasis target adenosine hosphoribosyltransferase. J. Org. Chem. 71:8685-8690.

128 Kahla-Nakbi A, Haouas N, Ouaer AE, Guerbej H, Mustapha KB, Babba H. 2010. Screening of 129 antileishmanial activity from marine sponge extracts collected off the Tunisian coast. Parasitol. Res. $130 \quad 106: 1281-1286$.

131 Lockshin RA, Zakeri Z. 2004. Apoptosis, autophagy, and more. Int J Biochem Cell Biol 36:2405-19.

132 Monte Neto RL, Sousa LMA, Dias CS, Barbosa Filho JM, Oliveira MR, Figueiredo RCBQ. 2011. 133 Morphological and physiological changes in Leishmania promastigotes induced by yangambin, a 134 lignan obtained from Ocotea duckei. Exp. Parasitol. 127:215-221.

135 Reyes C, Zbakh H, Motilva V, Zubía E. 2013. Antioxidant and anti-inflammatory meroterpenoids 136 from the brown alga Cystoseira usneoides. J. Nat. Prod. 76:621-629.

137 Rodrigues A, Farias L, Carvalho A, Santos A, Nascimento J, Silva E. 2014. A novel function for Kojic 138 acid, a secondary metabolite from Aspergillus fungi, as antileishmanial agent. PLoS One. 9:e91259.

139 Spavieri J, Allmendinger A, Kaiser M, Casey R, Hingley-Wilson S, Lalvani A, Guiry MD, Blunden G, 140 Tasdemir D. 2010. Antimycobacterial, antiprotozoal and cytotoxic potential of twenty-one brown 141 algae (Phaeophyceae) from British and Irish waters. Phytother. Res. 24:1724-1729.

142 Sundar S, Chakravarty J. 2015. Investigational drugs for visceral leishmaniasis. Expert Opin. Investig. 143 Drugs. 20:43-59.

144 Süzgeç-Selçuk S, Meriçli AH, Güven KC, Casey R, Hingley-Wilson S, Lalvani A, Guiry MD, 145 Blunden G, Tasdemir D. 2010. Evaluation of Turkish seaweeds for antiprotozoal, antimycobacterial 146 and cytotoxic activities. Phytother. Res. 25:778-783.

147 Tempone AG, Martins de Oliveira C, Berlinck RG. 2011. Current approaches to discover marine 148 antileishmanial natural products. Planta Medica. 77:572-585.

149 Vassallo O, Castelli S, Biswas A, Sengupta S, Das PK, D’Annessa I, Oteri F, Leoni A, Tagliatesta P, 150 Majumder HK, Desideri A. 2011. Conjugated eicosapentaenoic acid (cEPA) inhibits L. donovani 151 topoisomerase $\mathrm{I}$ and has an antiproliferative activity against $L$. donovani promastigotes. Open 152 Antimicrob. Ag. J. 3:23-29.

153 Yamthe LR, Appiah-Opong R, Fokou PVT, Tsabang N, Boyom FF, Nyarko AK, Wilson MD. 1542017 Marine algae as source of novel antileishmanial drugs: A review. Mar. Drugs. 15:323 


\section{FIGURE CAPTIONS}

156 Figure 1. Effect of the L. infantum and mammalian cells treatment with Cystoseira spp.

157 active hexane extracts and the reference drug Miltefosine. Significant differences between

158 extracts and reference drug are indicated as *,p $<0.05 ; * *, \mathrm{p}<0.01$; ***, $\mathrm{p}<0.001$ (Student's 159 t-test). 


\section{SUPPLEMENTARY MATERIAL}

3 Report of in vitro antileishmanial properties of Iberian macroalgae 4

5Carolina Bruno de Sousa ${ }^{1}$, João Henrique G. Lago ${ }^{2}$, Jorge Macridachis ${ }^{1}$, Marta 6Oliveira ${ }^{1,3}$, Luis Brito ${ }^{1}$, Catarina Vizetto-Duarte ${ }^{1}$, Cláudia Florindo ${ }^{4,5}$, Sarah 7Hendrickx ${ }^{6}$, Louis Maes ${ }^{6}$, Thiago Morais ${ }^{2}$, Miriam Uemi ${ }^{2}$, Luís Neto ${ }^{7}$, Lídia 8Dionísio ${ }^{7}$, Sofia Cortes $^{3}$, Luísa Barreira ${ }^{1}$, Luísa Custódio ${ }^{1}$, Fernando Alberício ${ }^{8}$, 9Lenea Campino ${ }^{3}$ and João Varela ${ }^{1 *}$

10

$11^{l}$ Centre of Marine Sciences, University of Algarve, Campus de Gambelas, 8005-139 Faro, Portugal.

$12^{2}$ Instituto de Ciências Ambientais, Químicas e Farmacêuticas, Universidade Federal de São Paulo, São

13 Paulo 09972-270, Brazil.

$14^{3}$ Global Health and Tropical Medicine Centre, Instituto de Higiene e Medicina Tropical, Universidade

15 Nova de Lisboa, 1349-008 Lisboa, Portugal.

$16^{4}$ Programa de Medicina Regenerativa, Departamento de Ciências Biomédicas e Medicina, UAlg, 8005-

17139 Faro, Portugal.

$18^{5}$ Centro de Investigação Biomédica, University of Algarve, 8005-139 Faro, Portugal.

$19^{6}$ Department of Biomedical Sciences, Faculty of Pharmaceutical, Biomedical and Veterinary Sciences,

20 Antwerp University, Antwerp, Belgium.

$21^{7}$ Faculdade de Ciências e Tecnologia, University of Algarve, Faro, Portugal.

$22^{8}$ Institute for Research in Biomedicine, Barcelona Science Park, Barcelona, Spain.

23

24* Corresponding author. Email: jvarela@ualg.pt 


\section{Abstract}

26Here is reported the anti Leishmania infantum activity of 45 hexane, dichloromethane and 27ethanol extracts from 16 macroalgae collected on the Iberian Coast. Seven hexane and 28dichloromethane Cystoseira baccata, C.barbata, C. tamariscifolia, C. usneoides, Dictyota 29spiralis and Plocamium cartilagineum extracts were active towards promastigotes $\left(\right.$ IC $_{50} 29.8$ $30101.8 \mu \mathrm{g} / \mathrm{mL}$ ) inducing strong morphological alterations in the parasites. Hexane extracts of $C$. 31 baccata and $C$. barbata were also active against intracellular amastigotes $\left(\mathrm{IC}_{50} 5.1\right.$ and 6.8 $32 \mu \mathrm{g} / \mathrm{mL}$, respectively). Fatty acids, triacylglycerols, carotenoids, steroids, and meroterpenoids 33were detected by nuclear magnetic resonance (NMR), and gas chromatography (GC) in the 34Cystoseira extracts. These results suggest that Cystoseira macroalgae contain compounds with 35antileishmanial activity, which could be explored as scaffolds to the development of novel 36sources of antiparasitic derivatives.

37Keywords: Antiparasitic, Leishmania infantum; Leishmaniasis; Macroalgae; Cystoseira; 38Secondary metabolites. 


\section{Experimental Section}

\section{Algal Material}

41 Samples from 15 different species belonging to the Rhodophyta, Chlorophyta and 42Heterokontophyta phyla were collected between July, 2010 and July, 2013 at different locations 43of the Portuguese and Spanish coasts (Table S1). Morphological identification was made by Dr 44Aschwin Engelen, Dr Tânia Pereira and MSc Mafalda Tavares (CCMAR-UAlg), Dr Javier 45Cremades (Facultad de Ciencias, University of A Coruña, Spain) and Dr Ricardo Bermejo 46(University of Cadiz, Spain). Biomass was washed with water to remove epiphytes, before 47freeze-drying, then grounded and stored at $-20{ }^{\circ} \mathrm{C}$ until use. Vouchers specimens are kept at 48MarBiotech herbarium at the Centre of Marine Sciences, Faro, Portugal.

49

\section{Extracts preparation}

51 Dried biomass was blended with hexane $(1: 10 \mathrm{w} / \mathrm{v})$ by means of an IKA Ultra-Turrax 52disperser for $1 \mathrm{~min}$ for cell wall disruption, and after centrifugation $(5000 \times g, 10 \mathrm{~min})$ the 53supernatants were recovered. The extraction was repeated three times. The residue was then 54sequentially extracted with $\mathrm{CH}_{2} \mathrm{Cl}_{2}$ and $\mathrm{MeOH}$ in a similar manner. All extracts were evaporated 55under reduced pressure at $40{ }^{\circ} \mathrm{C}$ and stored at $4{ }^{\circ} \mathrm{C}$. For the bioactivity assays, extracts were 56dissolved in DMSO (dimethyl sulfoxide) at the concentration of $50 \mathrm{mg} / \mathrm{mL}$.

57

\section{Chemical characterization of Cystoseira extracts}

\subsection{NMR analysis}

60 Hydrogen nuclear magnetic resonance $\left({ }^{1} \mathrm{H}\right.$ NMR) spectra were recorded on a Bruker Avance 61III 500 spectrometer, using $5 \mathrm{~mm}$ TXI probe, operated at $500.13 \mathrm{MHz}$ for ${ }^{1} \mathrm{H}$ nucleus. 62Approximately $10 \mathrm{mg}$ of each sample was dissolved in $0.6 \mathrm{~mL}$ of $\mathrm{CDCl}_{3}$ with tetramethylsilane 63(TMS) as a standard reference with a chemical shift $\delta_{\mathrm{H}}=0.00 \mathrm{ppm}$. Spectra were obtained at 25 $64^{\circ} \mathrm{C}$, with 64 scans, 2 dummy scans, using a 90-degree high power pulse of $8.3 \mu$ s, a recycle delay 65of 1s, and $64 \mathrm{~K}$ data points covering a spectral width of $7684 \mathrm{~Hz}$. All spectra were processed 66using Topspin 3.2 software.

67

683.2. GC/FID and GC/LREIMS analysis 
69 Gas chromatography with flame ionization detector (GC/FID) chromatograms were 70recorded on a Shimadzu GC-2010 gas chromatograph equipped with an FID-detector and an 71automatic injector (Shimadzu AOC-20i) using a RtX-5 capillary column (5\% phenyl, 95\% 72polydimethylsiloxane, $30 \mathrm{~m} \times 0.32 \mathrm{~mm} \times 0.25 \mu \mathrm{m}$ film thickness; Restek, USA). These analyses 73were performed by injecting $1.0 \mu \mathrm{L}$ of a $1.0 \mathrm{mg} / \mathrm{mL}$ solution of crude hexane extract in hexane in 74a split mode (1:30) employing helium as the carrier gas $(1 \mathrm{~mL} / \mathrm{min})$ under the following 75conditions: injector and detector temperatures of $+270{ }^{\circ} \mathrm{C}$ and $300{ }^{\circ} \mathrm{C}$, respectively; oven 76programmed temperature from $120-290{ }^{\circ} \mathrm{C}$ at $8{ }^{\circ} \mathrm{C} / \mathrm{min}$, holding $20 \mathrm{~min}$ at $290{ }^{\circ} \mathrm{C}$. Gas

77chromatography-low resolution electron ionization mass spectrometry (GC/LREIMS) analysis 78was conducted in a Shimadzu GC-17A chromatograph interfaced with a MS-QP-5050A mass 79spectrometer operating using ionization voltage of $70 \mathrm{eV}$ and an ion source temperature of +350 $80^{\circ} \mathrm{C}$ with the same conditions described above. Helium was used as the carrier gas.

81

\section{Antileishmanial and cytotoxicity assays}

834.1. Cytotoxicity against human acute monocytic leukaemia cell line THP-1

84 Cytotoxicity of all extracts was performed on human acute monocytic leukaemia cell line 85THP-1 (ATCC TIB-202). Cells were cultivated in RPMI-1640 medium supplemented with 10\% 86heat-inactivated foetal bovine serum (FBS), L-glutamine $(2 \mathrm{mM})$, penicillin $(50 \mathrm{U} / \mathrm{L})$ and 87streptomycin $(0.05 \mathrm{mg} / \mathrm{L})$ at $37{ }^{\circ} \mathrm{C}$ in humidified atmosphere with $5 \% \mathrm{CO}_{2}$. For the assay, $10^{5}$ 88THP-1 cells per well were seeded onto the 96-well plates. Extracts were added at concentrations 89ranging from 4 to $125 \mu \mathrm{g} / \mathrm{mL}$ for $48 \mathrm{~h}$, and cell viability was determined by the MTT (3-(4,590dimethylthiazol-2-yl)-2,5-diphenyltetrazolium bromide) colorimetric assay, as described 91elsewhere (Dutta et al., 2005). Cells used as negative control were treated with DMSO at the 92highest concentration used in test wells $(0.5 \% \mathrm{v} / \mathrm{v})$. Results were expressed in terms of cell 93viability (\%) and half maximal inhibitory concentration values $\left(\mathrm{IC}_{50}-\right.$ in $\left.\mu \mathrm{g} / \mathrm{mL}\right)$.

94

\subsection{Antipromastigote assay}

96 Promastigote forms of a L. infantum strain (MHOM/PT/88/IMT-151) were obtained from 97the cryobank of the 'Instituto de Higiene e Medicina Tropical' (Universidade Nova de Lisboa, 98Portugal) and maintained in RPMI-1640 medium supplemented with 10\% FBS, L-glutamine, 99penicillin and streptomycin, at $24^{\circ} \mathrm{C}$. About $2 \times 10^{6}$ parasites per well were incubated in 96 -well 
100plates with the extracts at concentrations ranging from 4 to $125 \mu \mathrm{g} / \mathrm{mL}$ for $48 \mathrm{~h}$. Negative control 101cells were treated with DMSO at the highest concentration used in test wells $(\leq 1 \% \mathrm{v} / \mathrm{v})$. 102Amphotericin B $(0.2 \mu \mathrm{g} / \mathrm{mL})$, miltefosine $(12.7 \mu \mathrm{g} / \mathrm{mL})$ and pentamidine $(0.5 \mu \mathrm{g} / \mathrm{mL})$ were used 103as positive controls. The effect of the extracts on parasite viability was assessed by the MTT 104colorimetric assay. Results were expressed in terms of cell viability $(\%)$ and $\mathrm{IC}_{50}$ values $(\mu \mathrm{g} / \mathrm{mL})$. 105

\subsection{Activity against intracellular amastigotes}

107 L. infantum intracellular amastigotes (MHOM/MA(BE)/67) were collected from the spleen 108of heavily infected donor hamsters and used to infect primary peritoneal mouse macrophages 109(PMM). PMM ( $3 \times 10^{4}$ cells per well) were seeded on 96-well plates, and incubated for two days 110 for cell attachment. Then, $5 \times 10^{5}$ amastigotes were added to each well (infection ratio about 16 111 amastigotes per cell) and infected macrophages were further incubated at $37{ }^{\circ} \mathrm{C}$ for $2 \mathrm{~h}$. The 112extracts at concentrations ranging from 0.25 to $64.0 \mu \mathrm{g} / \mathrm{mL}$ were added and the plates were 113further incubated at $37{ }^{\circ} \mathrm{C}$ and $5 \% \mathrm{CO}_{2}$. After 5 days, intracellular amastigote burdens were 114microscopically assessed upon Giemsa staining and the inhibitory concentration conferring a $11550 \%$ reduction of the intracellular amastigote burden compared to the non-treated infected 116positive controls $\left(\mathrm{CC}_{50}\right)$ was determined. In addition, cytotoxicity of the extracts was evaluated 117on PMM cells and carried out as previously described (Cos et al., 2016). The reference drug 118(miltefosine) was used as positive control.

119 .

\subsection{Microscopic analysis}

121 Leishmania promastigotes were incubated with the extracts $(125 \mu \mathrm{g} / \mathrm{mL})$ and with 122amphotericin $(0.2 \mu \mathrm{g} / \mathrm{mL})$ for $48 \mathrm{~h}$. After incubation and centrifugation, parasites were smeared 123on microscope slides, fixed with methanol and stained with Giemsa solution and observed using 124a Zeiss AXIOMAGER Z2 microscope, equipped with a cool SNApHQ2 camera and AxioVision 125software version 4.8 (Carl Zeiss MicroImaging GmbH, Göttingen, Germany).

\subsection{Apoptosis detection through annexin V-FITC staining}

128Promastigotes $\left(4 \times 10^{6} / \mathrm{mL}\right)$ cultured in RPMI medium with DMSO $(0.1 \%)$ were treated with $129 \mathrm{IC}_{50}$ concentrations of with Cystoseira extracts at $\mathrm{IC}_{50}$ concentrations for $48 \mathrm{~h}$. Negative and 130positive controls cells were treated with DMSO at the highest concentration used in test wells $(\leq$ 
$1311 \% \mathrm{v} / \mathrm{v})$ and amphotericin B $(0.6 \mu \mathrm{g} / \mathrm{mL})$, respectively. Apoptotic effect of the tested extracts on 132L. infantum promastigotes was evaluated by flow cytometry using the Annexin V-FITC 133(fluorescein isothiocyanate) Apoptosis Kit - KA0714 (Abnova) in accordance with the 134manufacturer's recommendations. Briefly, treated and control promastigotes were washed with 135 culture medium and resuspended in $500 \mu \mathrm{L}$ binding buffer and stained with $5 \mu \mathrm{L}$ of annexin V136FITC $(10 \mathrm{mg} / \mathrm{mL})$ and $5 \mu \mathrm{l}$ of propidium iodide (PI; $50 \mu \mathrm{g} / \mathrm{ml})$ and incubate at room temperature 137 for $5 \mathrm{~min}$ in the dark. Results were obtained by flow cytometry using a FACS Calibur Flow 138Cytometer (Becton-Dickinson, East Rutherford, NJ, USA) using the Cell Quest software (BD 139Biosciences, San Jose, CA, USA) for acquisition and result analysis. Ten thousand events were 140 analysed and apoptosis evaluated based on the geometric mean of the fluorescence intensity 141detected in channels 1 (for annexin) and 2 (for PI) (Farias et al., 2013).

142

\section{Statistical analysis}

144 The antileishmanial and cytotoxic assays were conducted in triplicate and the results were 145 expressed as mean and standard error of the mean (SEM). The $\mathrm{IC}_{50}$ values were calculated using 146sigmoid regression on the logarithm of the concentration-response data in the GraphPad Prism V 1475.0 software. Student's t-test was used to determine whether differences between means were 148significant at different levels $(p<0.05$ and $p<0.01)$.

149

150References

151Dutta A, Bandyopadhyayb S, Mandala C, Chatterjeeb M. 2005. Development of a modified 152MTT assay for screening antimonial resistant field isolates of Indian visceral leishmaniasis. 153Parasitol. Int. 54:119-122.

154Cos P, Vlietinck AJ, Vanden Berghe D, Maes L. 2016. Anti-infective potential of natural 155products: how to develop a stronger in vitro proof-of-concept. J. Ethnopharmacol. 106:290-302.

156Farias LH, Rodrigues AP, Silveira FT, Seabra SH, DaMatta RA, Saraiva EM, Silva EO. 2013. 157Phosphatidylserine exposure and surface sugars in two Leishmania (Viannia) braziliensis strains 158involved in cutaneous and mucocutaneous leishmaniasis. J. Infect. Dis. 207(3):537-43. 


\section{Tables}

160

161Table S1. Species, date of collection and collection site of the macroalgae used in this study

\begin{tabular}{|c|c|c|c|}
\hline Phylum /Species & Date & Local & Country \\
\hline \multicolumn{4}{|l|}{ Chlorophyta } \\
\hline Cladophora albida (Nees) Kutzing & July 2010 & Olhos de Água ${ }^{1}$ & Portugal \\
\hline Codium sp. Stackhouse & July 2010 & Olhos de Água ${ }^{1}$ & Portugal \\
\hline \multicolumn{4}{|l|}{ Heterokontophyta } \\
\hline Cladostephus spongiosus (Hudson) C. Agardh & July 2010 & Olhos de Água ${ }^{1}$ & Portugal \\
\hline Cystoseira baccata (S. G. Gmelin) P. C. Silva & July 2012 & $\operatorname{Areosa}^{2}$ & Portugal \\
\hline Cystoseira barbata (Stackhouse) C. Agardh & March 2013 & Cadiz Bay $^{1}$ & Spain \\
\hline Cystoseira humilis Schousboe ex Kützing & May 2012 & Almograve ${ }^{3}$ & Portugal \\
\hline Cystoseira nodicaulis (Withering) M. Roberts & April 2013 & Santa Mariña $^{2}$ & Spain \\
\hline Cystoseira tamariscifolia (Hudson) Papenfuss & July 2012 & Areosa $^{2}$ & Portugal \\
\hline Cystoseira usneoides (L.) M. Roberts & September 2012 & Olhos de Água ${ }^{1}$ & Portugal \\
\hline Halopteris scoparia (L.) Sauvageau & July 2010 & Olhos de Água ${ }^{1}$ & Portugal \\
\hline Sargassum muticum (Yendo) Fensholt & July 2010 & Olhos de Água ${ }^{1}$ & Portugal \\
\hline Taonia atomaria (Woodward) J. Agardh & July 2010 & Olhos de Água ${ }^{1}$ & Portugal \\
\hline \multicolumn{4}{|l|}{ Rhodophyta } \\
\hline Peyssonnelia squamaria (S. G. Gmelin) Decaisne & July 2013 & Arrifes $^{1}$ & Portugal \\
\hline Plocamium cartilagineum (L.) P. S. Dixon & July 2012 & Olhos de Água ${ }^{1}$ & Portugal \\
\hline Scinaia furcellata (Turner) J. Agardh & July 2013 & Olhos de Água ${ }^{1}$ & Portugal \\
\hline
\end{tabular}

${ }^{1}$ Southern coast, ${ }^{2}$ Northwestern coast and ${ }^{3}$ Southwestern coast of the Iberian Peninsula. 
164Table S2. Inhibitory concentrations of algal extracts against $L$. infantum and mammalian 165cells

\begin{tabular}{|c|c|c|c|c|}
\hline Species & $\begin{array}{c}\text { Extract/ } \\
\text { Compound }\end{array}$ & $\begin{array}{l}\mathrm{IC}_{50}(\mu \mathrm{g} / \mathrm{mL})^{\mathrm{a}} \\
\text { Promastigotes }\end{array}$ & $\begin{array}{c}\mathrm{CC}_{50}(\mu \mathrm{g} / \mathrm{mL})^{\mathrm{b}} \\
\text { Amastigotes }\end{array}$ & $\begin{array}{c}\mathrm{IC}_{50}(\mu \mathrm{g} / \mathrm{mL})^{\mathrm{a}} \\
\mathrm{THP}-1\end{array}$ \\
\hline \multirow[t]{3}{*}{ Cladophora albida } & Hexane & $>125$ & - & $>125$ \\
\hline & $\mathrm{CH}_{2} \mathrm{Cl}_{2}$ & $>125$ & - & $>125$ \\
\hline & $\mathrm{MeOH}$ & $>125$ & - & $>125$ \\
\hline \multirow[t]{3}{*}{ Cladostephus spongiosus } & Hexane & $>125$ & - & $>125$ \\
\hline & $\mathrm{CH}_{2} \mathrm{Cl}_{2}$ & $>125$ & - & $>125$ \\
\hline & $\mathrm{MeOH}$ & $>125$ & - & $>125$ \\
\hline \multirow[t]{3}{*}{ Cystoseira baccata } & Hexane & $94.1 \pm 1.5$ & $5.1 \pm 0.0$ & $>125$ \\
\hline & $\mathrm{CH}_{2} \mathrm{Cl}_{2}$ & $>125$ & - & $76.2 \pm 3.9$ \\
\hline & $\mathrm{MeOH}$ & $>125$ & - & $>125$ \\
\hline \multirow[t]{3}{*}{ Cystoseira barbata } & Hexane & $78.7 \pm 3.2$ & $6.8 \pm 0.0$ & $79.5 \pm 2.3$ \\
\hline & $\mathrm{CH}_{2} \mathrm{Cl}_{2}$ & $>125$ & - & $>125$ \\
\hline & $\mathrm{MeOH}$ & $>125$ & - & $>125$ \\
\hline \multirow[t]{3}{*}{ Cystoseira humilis } & Hexane & $>125$ & - & $>125$ \\
\hline & $\mathrm{CH}_{2} \mathrm{Cl}_{2}$ & $>125$ & - & $>125$ \\
\hline & $\mathrm{MeOH}$ & $>125$ & - & $>125$ \\
\hline \multirow[t]{3}{*}{ Cystoseira tamariscifolia } & Hexane & $31.2 \pm 0.9$ & - & $30.9 \pm 0.4$ \\
\hline & $\mathrm{CH}_{2} \mathrm{Cl}_{2}$ & $29.8 \pm 0.5$ & - & $19.9 \pm 0.5$ \\
\hline & $\mathrm{MeOH}$ & $>125$ & - & $>125$ \\
\hline \multirow[t]{3}{*}{ Cystoseira nodicaulis } & Hexane & $>125$ & - & $>125$ \\
\hline & $\mathrm{CH}_{2} \mathrm{Cl}_{2}$ & $>125$ & - & $>125$ \\
\hline & $\mathrm{MeOH}$ & $>125$ & - & $>125$ \\
\hline \multirow[t]{3}{*}{ Cystoseira usneoides } & Hexane & $59.9 \pm 0.2$ & - & $16.6 \pm 0.3$ \\
\hline & $\mathrm{CH}_{2} \mathrm{Cl}_{2}$ & $33.6 \pm 0.6$ & - & $12.6 \pm 0.4$ \\
\hline & $\mathrm{MeOH}$ & $>125$ & - & $45.0 \pm 0.4$ \\
\hline \multirow{3}{*}{ Codium sp. } & Hexane & $>125$ & - & $>125$ \\
\hline & $\mathrm{CH}_{2} \mathrm{Cl}_{2}$ & $>125$ & - & $>125$ \\
\hline & $\mathrm{MeOH}$ & $>125$ & - & $>125$ \\
\hline \multirow[t]{3}{*}{ Dictyota spiralis } & Hexane & $48.3 \pm 0.7$ & - & - \\
\hline & $\mathrm{CH}_{2} \mathrm{Cl}_{2}$ & $>125$ & - & - \\
\hline & $\mathrm{MeOH}$ & $>125$ & - & - \\
\hline \multirow{3}{*}{ Halopteris scoparia } & Hexane & $>125$ & - & $>125$ \\
\hline & $\mathrm{CH}_{2} \mathrm{Cl}_{2}$ & $>125$ & - & $>125$ \\
\hline & $\mathrm{MeOH}$ & $>125$ & - & $>125$ \\
\hline \multirow[t]{3}{*}{ Peysonnelia squamaria } & Hexane & $>125$ & - & $>125$ \\
\hline & $\mathrm{CH}_{2} \mathrm{Cl}_{2}$ & $>125$ & - & $>125$ \\
\hline & $\mathrm{MeOH}$ & $>125$ & - & $>125$ \\
\hline \multirow[t]{3}{*}{ Plocamium cartilagineo } & Hexane & $101.8 \pm 2.8$ & - & $51.6 \pm 0.1$ \\
\hline & $\mathrm{CH}_{2} \mathrm{Cl}_{2}$ & $>125$ & - & $>125$ \\
\hline & $\mathrm{MeOH}$ & $>125$ & - & $>125$ \\
\hline \multirow[t]{3}{*}{ Sargassum muticum } & Hexane & $>125$ & - & $>125$ \\
\hline & $\mathrm{CH}_{2} \mathrm{Cl}_{2}$ & $>125$ & - & $>125$ \\
\hline & $\mathrm{MeOH}$ & $>125$ & - & $>125$ \\
\hline \multirow{3}{*}{ Scinaria funcellata } & Hexane & $>125$ & - & $>125$ \\
\hline & $\mathrm{CH}_{2} \mathrm{Cl}_{2}$ & $>125$ & - & $>125$ \\
\hline & $\mathrm{MeOH}$ & $>125$ & - & $>125$ \\
\hline
\end{tabular}




\begin{tabular}{|c|c|c|c|c|}
\hline Species & $\begin{array}{c}\text { Extract/ } \\
\text { Compound }\end{array}$ & $\begin{array}{l}\mathrm{IC}_{50}(\mu \mathrm{g} / \mathrm{mL})^{\mathrm{a}} \\
\text { Promastigotes }\end{array}$ & $\begin{array}{c}\mathrm{CC}_{50}(\mu \mathrm{g} / \mathrm{mL})^{\mathrm{b}} \\
\text { Amastigotes }\end{array}$ & $\begin{array}{c}\mathrm{IC}_{50}(\mu \mathrm{g} / \mathrm{mL})^{\mathrm{a}} \\
\text { THP-1 }\end{array}$ \\
\hline \multirow[t]{3}{*}{ Taonia atomaria } & Hexane & $>125$ & - & $>125$ \\
\hline & $\mathrm{CH}_{2} \mathrm{Cl}_{2}$ & $>125$ & - & $>125$ \\
\hline & $\mathrm{MeOH}$ & $>125$ & - & $>125$ \\
\hline \multirow[t]{3}{*}{ Positive controls } & Miltefosine & $12.7 \pm 1.8$ & $8.8 \pm 0.0$ & $8.8 \pm 0.0$ \\
\hline & Amphotericin & $0.2 \pm 0.0$ & - & - \\
\hline & Pentamidine & $0.5 \pm 0.1$ & - & - \\
\hline
\end{tabular}

${ }^{\mathrm{a}} \mathrm{IC}_{50}$ - Inhibitory concentration of extract / compound causing $50 \%$ reduction of the promastigote and human acute monocytic leukaemia cell line THP-1 cells growth; ${ }^{\mathrm{b}} \mathrm{CC}_{50}$ - Inhibitory concentration of extract / compound causing 50\% reduction of the intracellular amastigote burden compared to the nontreated infected controls. $\mathrm{IC}_{50}$ and $\mathrm{CC}_{50}$ values represent the mean \pm standard error of the mean of three experiments performed in triplicate. 
167Table S3. Class of metabolites found in Cystoseira extracts

\begin{tabular}{|c|c|c|}
\hline Species & Extracts & Class of metabolites ${ }^{1}$ \\
\hline \multirow[t]{3}{*}{ C. baccata } & Hexane & FA, TAG, CAR, ST \\
\hline & $\mathrm{CH}_{2} \mathrm{Cl}_{2}$ & $\mathrm{MT}, \mathrm{FA}$ \\
\hline & $\mathrm{MeOH}$ & MT \\
\hline \multirow[t]{3}{*}{ C. barbata } & Hexane & FA, TAG, CAR, ST \\
\hline & $\mathrm{CH}_{2} \mathrm{Cl}_{2}$ & MT, FA \\
\hline & $\mathrm{MeOH}$ & MT \\
\hline \multirow[t]{3}{*}{ C. humilis } & Hexane & FA, TAG, CAR \\
\hline & $\mathrm{CH}_{2} \mathrm{Cl}_{2}$ & FA \\
\hline & $\mathrm{MeOH}$ & FA, MT \\
\hline \multirow[t]{3}{*}{ C. nodicaulis } & Hexane & FA, TAG, CAR, ST \\
\hline & $\mathrm{CH}_{2} \mathrm{Cl}_{2}$ & MT, FA \\
\hline & $\mathrm{MeOH}$ & FA \\
\hline \multirow[t]{3}{*}{ C. tamariscifolia } & Hexane & FA, TAG, CAR \\
\hline & $\mathrm{CH}_{2} \mathrm{Cl}_{2}$ & MT, FA \\
\hline & $\mathrm{MeOH}$ & MT \\
\hline \multirow[t]{3}{*}{ C. usneoides } & Hexane & MT, FA \\
\hline & $\mathrm{CH}_{2} \mathrm{Cl}_{2}$ & MT, FA \\
\hline & $\mathrm{MeOH}$ & MT \\
\hline
\end{tabular}

${ }^{1}$ FA - fatty acids, TAG - triacylglycerols, CAR - carotenoids, ST - steroids, MT - meroterpenoids 


\section{Figures}

169

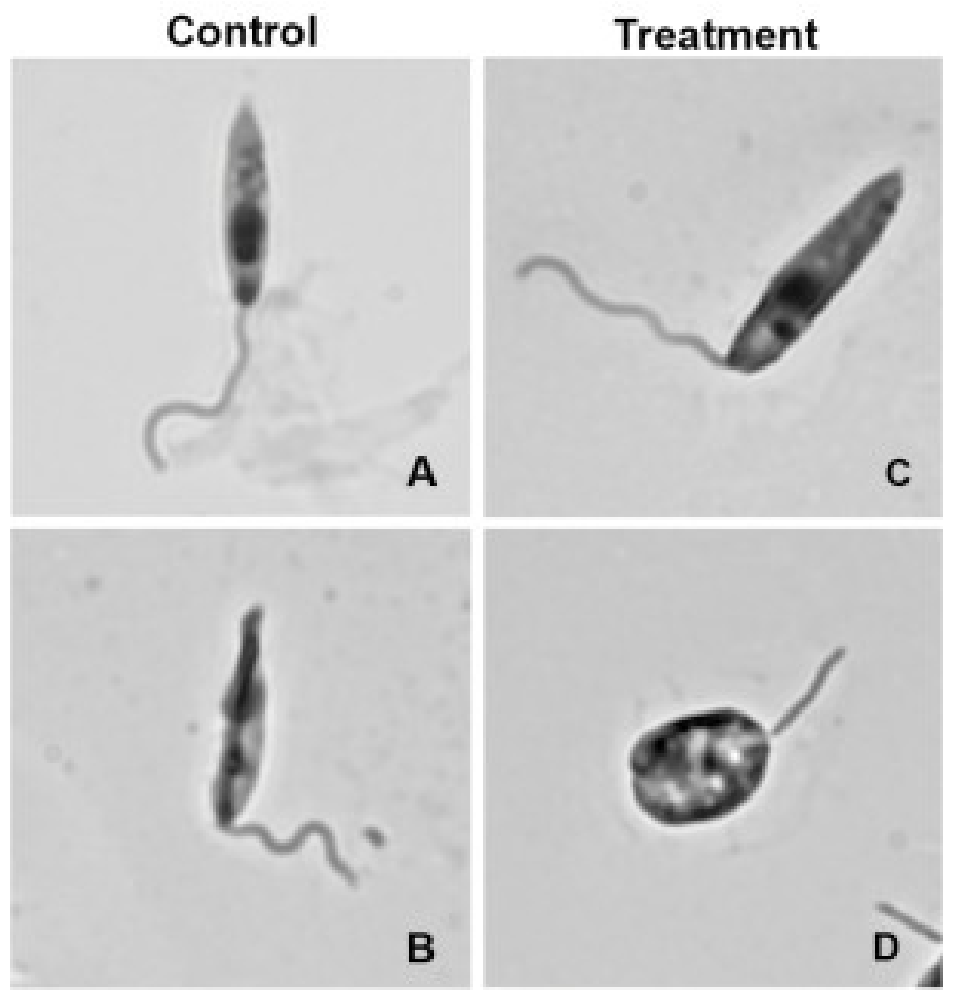

170Figure S1. Effect of $C$. nodicaulis and C. barbata hexane extracts $(125 \mu \mathrm{g} / \mathrm{mL}, 48 \mathrm{~h})$ on the 171morphology of L. infantum promastigotes. Control cells cultured in RPMI medium alone (A) 172treated with the control drug amphotericin B $(0.2 \mu \mathrm{g} / \mathrm{mL} ; \mathbf{B})$, and treated with $C$. nodicaulis $(\mathbf{C})$ 173or C. barbata (D) extracts. Bright field images; the scale bar corresponds to $5 \mu \mathrm{m}$. 




176Figure S2. ${ }^{1} \mathrm{H}$ NMR spectra $\left(500 \mathrm{MHz}, \mathrm{CDCl}_{3}\right)$ of the Cystoseira baccata (A), C. barbata (B) C. 177 tamariscifolia $(\mathbf{C})$ and C. usneoides $(\mathbf{D})$ hexane extracts. 


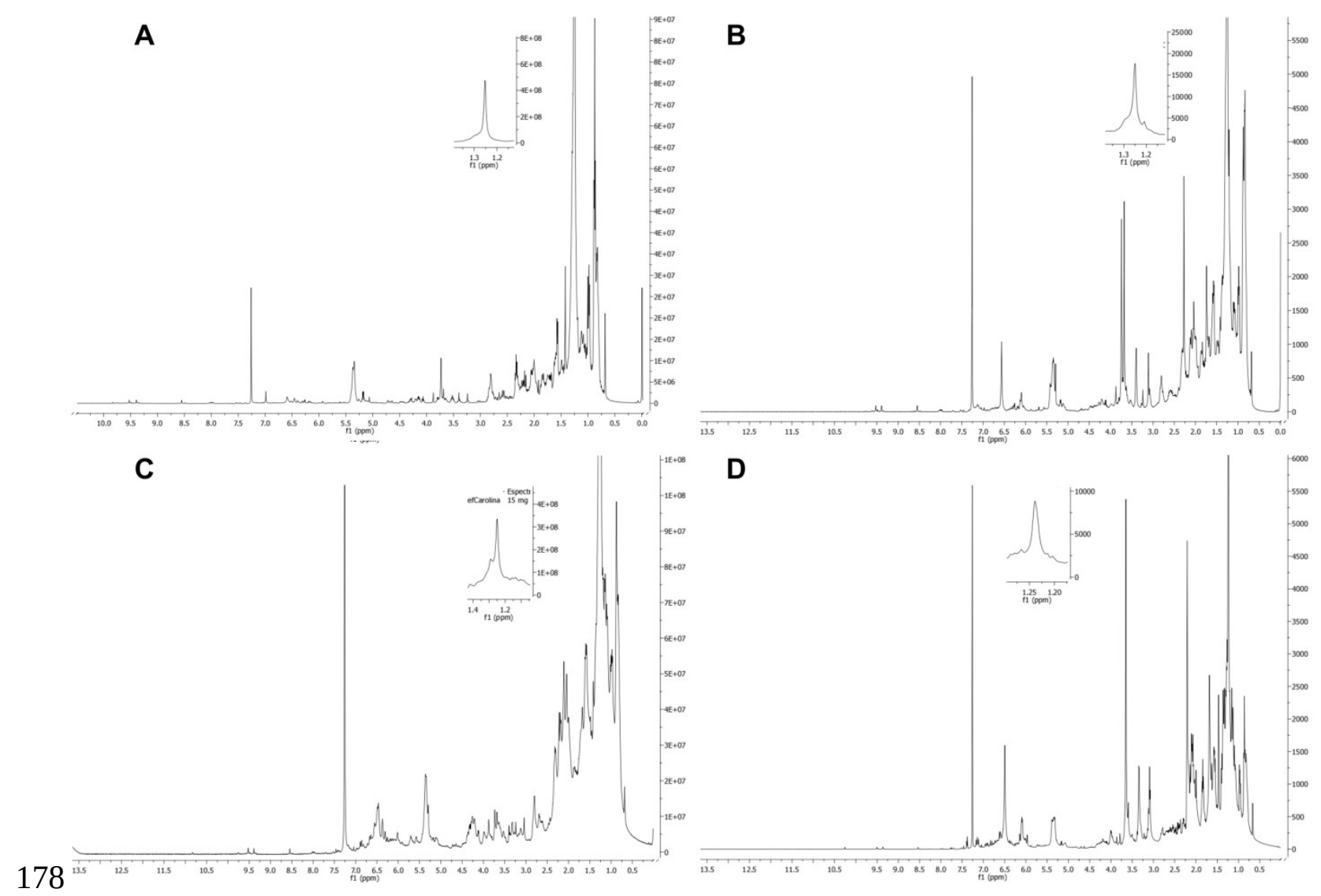

179Figure S3. ${ }^{1} \mathrm{H}$ NMR spectra $\left(500 \mathrm{MHz}, \mathrm{CDCl}_{3}\right)$ of the Cystoseira. baccata (A), C. barbata (B), 180C. tamariscifolia $(\mathbf{C})$ and C. usneoides $(\mathbf{D}) \mathrm{CH}_{2} \mathrm{Cl}_{2}$ extracts.

181

182 